when tapped, yield scarcely any rubber, the difference between them and the rubber-trees of the Charduar Forest being probably due to the greater dampness of the atmosphere and soil in the latter locality, as compared with the Brahmaputra Valley.

An area only of 8 acres was therefore planted out near Tezpur, whilst the area of the Charduar plantation in 1889 , was I IO6 acres, and contained 16,054 plants, besides large nurseries with 84,000 seedlings.

Local Governments in India, which have to find funds for all sorts of administrative purposes, are naturally inclined to econo mize, and Sir Charles Eliot, when Chief Commissioner of Assam, about ten years ago, proposed to stop further work on the Charduar plantation, but this was vigorously opposed by Dr. Schlich, the Inspector-General of Forests, and at his advice, the Government of India directed the further extension of the plantation. Apparently, however, little progress was made between I88I and 1888 , when an additional area of 63 acres was planted up. Regarding the growth of the plants, the following figures, taken from Mr. Mann's report on the Assam forest administration for I888-89, give the average height and girth, up to April I 889 , of 50 trees in each year's planting :--

\begin{tabular}{|c|c|c|c|c|c|c|c|c|}
\hline \multirow{2}{*}{ Year when planted. } & \multicolumn{4}{|c|}{ Average } & \multicolumn{4}{|c|}{ Growth since last year. } \\
\hline & $\mathrm{Hei}$ & ight. & & irth. & & eight. & & irth. \\
\hline & Feet. & Inches. & Feet. & Inches. & Feet. & Inches. & Feet. & Inches. \\
\hline$x 874-75$ & $6 I$ & II & I I & 5 & 6 & I & 0 & 9 \\
\hline $1875-76$ & 57 & 6 & 7 & IO & 5 & 2 & o & 6 \\
\hline I $876-77$ & 55 & Io & 7 & 5 & 3 & 7 & 0 & 6 \\
\hline $1877-78$ & 53 & 9 & 5 & I I & 5 & 3 & o & 7 \\
\hline $1878-79$ & 46 & 2 & 4 & 6 & 4 & o & o & 5 \\
\hline $1879-80$ & 44 & 10 & 5 & 2 & 5 & 9 & I & 2 \\
\hline $1880-8 I$ & 38 & 7 & & 2 & 6 & 7 & $\mathrm{o}$ & 8 \\
\hline
\end{tabular}

Thus, we see that the present average annual growth in height and girth, taken from $35^{\circ}$ plants, are respectively 5 feet 2 inches and 8 inches.

In the small Tezpur plantation, where there are now 794 plants, all of 1874 , the average height and girth are 47 feet 3 inches and ro feet Io inches respectively, the average growth in one year being 4 feet 4 inches in height.

The up-keep of the plantation consists chiefly in clearing the lines round the plants, but four years after planting the undergrowth is well kept down by the shade of the rubber-trees.

Experimental tappings were made in 1883 and 1884 on 50 natural grown rubber-trees in the Charduar Forest, the total yield being $43^{8}$ pounds in 1883 , and 206 pounds in 1884 , giving an average yearly yield of $6 \frac{1}{2}$ pounds per tree. Further information regarding the yield of rubber from trees in the Assam forests would doubtless be procurable from the Assam Forest Office, as well as statistics of the cost of the plantations, which are not given in the papers at present before me. W. R. FISHER.

Cooper's Hill College, February i 8 .

\section{Snow on the Branches of Trees.}

FOLLOWING upon the remarkable ice-storm of which I wrote you last month (NATURE, February 5, p. 3I7), we have had a wonderful and beautiful display of the amount of snow which the branches of trees can bear. There had been the beginning of an ice-storm on Sunday last; and on Monday, the gth instant, there followed a damp but light snow which fell rapidly in a calm atmosphere. The whole appearance of trees and air and sky was very beautiful. Some of the trees caught a large quantity of snow, fastened to the branches in a form resembling elliptical cylinders, of which the lower lines of the branches were elements. I made some measurements on the extremities of drooping branches of an elm-tree on our lower campus. One twig with a diameter of $0.2 \mathrm{I}$ inch sustained a mass of snow with diameters of 2.50 and 2.33 inches; a second, $O^{\circ} \cdot 5$ inch in diameter, carried snow the diameters of which were $2 \cdot 30$ and $\mathrm{I}^{\circ} 93$ inches; so that the area of the cross-sections of this snow was not far from 120 and 153 times that of the twigs which supported it. Two other measurements were still more remarkable. In one the twig was one-tenth of an inch in diameter, and the mass of snow had diameters of 2.40 and $I \cdot 75$ inches, making the area of the sections 420 times that of the wood; and in the other, a twig

NO. I I I 3 , VOL. 43$]$
0.11 inch in diameter, carried snow with diameters of 2.50 and 2.05 inches, so that the area of the sections of the snow was 424 times that of the wood. The snow was so loosely attached to the branches that it seemed impossible to make accurate measurements of the weight of the twigs and of the snow which was piled up on them; but the ratio of the weights was, of course, by no means equal to the ratio of the sections--which was practically that of the bulks-of the wood and the snow.

Trinity College, Hartford, Conn., U.S.A., February 12.

\section{Elementary Systematic Chemistry.}

I Do not as a general rule approve of a reply to a review, and so far as regards the part of the notice which refers to the short Chemistry which I have lately brought out, I have merely to thank your reviewer for the hints he has given in the last paragraphs, and for the friendly tone of his criticism.

But his first remarks open up a wide field, which appears to me to form a legitimate subject for discussion apart from the merits or demerits of any particular text-book.

The discussion turns on the age at which it is intended to begin the study of chemistry. I am all in favour of "children" playing with matter in all its forms; getting to know the appearance and properties of things in general; just as, indeed, very young children learn many useful facts from handling toys, and from the objects which daily come under their notice. But I do not acknowledge that playing with chemical materials constitutes a study of chemistry. To pursue your reviewer's simile, a child plays with language ; he learns to speak it, read it, and possibly write it reasonably well. But when he begins to study language, he must learn grammar. I am equally in favour of learning a foreign language by conversation and by promiscuous reading; but to know French and German, we must study the classification and derivation of their words, their connection with each other, and the means whereby they may be combined to form correct sentences.

Now my experience has been that the ordinary text-books of inorganic chemistry convey a large amount of heterogeneous information-the facts grouped in a certain order, it is true, but not in such order as to lead the beginner to generalize and classify. And indeed this is tacitly acknowledged by your reviewer in his remark, "The student who is already fairly acquainted with the subject will find the summary of properties, \&c., of much use," implying that such summaries are not easily obtained from ordinary text-books. The beginner in chemistry acquires a vast amount of information on isolated facts; great demands are made on his memory, and many students have formerly hinted to me that they find the study hopeless; there is so much to be remembered, and so little connection between the facts. This short text-book has been written with a view of removing this obstacle. In it facts are classified, general methods are set forth, and the properties of compounds common to all members of a group are to be found together. In the preface, $X$ have emphasized these views; but I did not intend to exclude the acquisition of general knowledge of matter, which may be acquired as thoroughly by this arrangement as by any other.

I am quite aware that a complete comprehension of the periodic law is beyond the young student; but a boy of fourteen or fifteen will learn to understand it better by this method than by any other, and at first he may accept the statement that experience (the experience of the writer, at least) has proved it to be the best way of presenting the subject.

WILliam Ramsay.

University College, Gower Street, W.C., February 20.

\section{Frozen Fish.}

Ir is not uncommon for small fish to be frozen to ice in shallow water. In $1838 \mathrm{I}$ put some of these frozen fish into tepid water, and they recovered. In 1852 , in one part of the lake at Highfield House, there must have been hundreds frozen to the ice, but when it melted scarcely any dead fish were seen : they had either recovered or had been devoured by pike. In 1860 a number of gold-fish were hard frozen, but recovered in warm water.

When ice is transparent the fish seen beneath are apparently healthy ; indeed, there always seem to be air-bubbles sufficient to sustain the life of fish.

I never saw pike, carp, tench, perch, or trout frozen to ice.

Shirenewton Hall, February $22 . \quad$ E. J. Lowe. 